\title{
Diet and trophic niche overlap of Boana bischoffi and Boana marginata (Anura: Hylidae) in southern Brazil
}

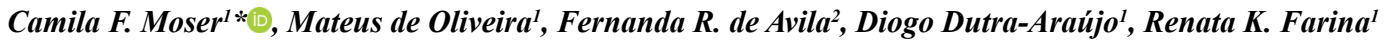 \\ and Alexandro M. Tozetti ${ }^{1}$ \\ ${ }^{1}$ Universidade do Vale do Rio dos Sinos, Laboratório de Ecologia de Vertebrados Terrestres, Av. Unisinos, 950, \\ Bairro Cristo Rei, CEP 93022-750, São Leopoldo, RS, Brasil \\ ${ }^{2}$ Universidade do Vale do Rio dos Sinos, Laboratório de Biologia Molecular, Av. Unisinos, 950, \\ Bairro Cristo Rei, CEP 93022-750, São Leopoldo, RS, Brasil \\ *Corresponding author: Camila F. Moser,e-mail: camila-moser@hotmail.com
}

MOSER, C.F., OLIVEIRA, M., AVILA, F.R., DUTRA-ARAÚJO, D., FARINA, R.K., TOZETTI, A.M. Diet and trophic niche overlap of Boana bischoffi and Boana marginata (Anura: Hylidae) in southern Brazil. Biota Neotropica. 19(1): e20180542. http://dx.doi.org/10.1590/1676-0611-BN-2018-0542

\begin{abstract}
The species Boana bischoffi and Boana marginata are endemic to the Atlantic Forest, where they often occur in sympatry. There is a large gap in the knowledge of natural history of both species. In this study, we aimed to describe and compare the diet composition of B. bischoffi and B. marginata in the southern domain of the Brazilian Atlantic Forest. We analyzed the gastrointestinal contents of 43 individuals of $B$. bischoffi and 30 individuals of B. marginata. Both showed a high trophic niche overlap $\left(0.90 \mathrm{O}_{\mathrm{jk}}\right)$. The most important prey categories for both species belonged to the orders Araneae and Coleoptera. The species niche breadth (Bsta) varied from 0.35 to 0.42, suggesting a generalist feeding behavior for both species. Our data provide unprecedented information on these species' food composition, contributing to a better knowledge of the natural history of neotropical anurans. Keywords: Trophic ecology, Atlantic forest, Niche breadth, Amphibians.
\end{abstract}

\section{Dieta e sobreposição de nicho trófico de Boana bischoffi e Boana marginata (Anura: Hylidae) no sul do Brasil}

\begin{abstract}
Resumo: As espécies Boana bischoffi e Boana marginata, são endêmicas da Mata Atlântica onde frequentemente ocorrem em simpatria. Existe uma grande lacuna no conhecimento da história natural de ambas as espécies. Nesse estudo, nosso objetivo foi descrever e comparar a composição da dieta de B. bischoffi e B. marginata no limite sul da Mata Atlântica brasileira. Analisamos o conteúdo gastrointestinal de 43 indivíduos de $B$. bischoffi e 30 indivíduos de B. marginata. Ambas apresentaram elevada sobreposição de seus nichos tróficos $\left(0,90 \mathrm{O}_{\mathrm{jk}}\right)$. As categorias de presas mais importantes para ambas as espécies pertenciam as ordens Araneae e Coleoptera. A amplitude de nicho das espécies (Bsta) variou de 0,35 a 0,42, sugerindo comportamento alimentar generalista para ambas. Nossos dados trazem informações inéditas sobre a composição alimentar destas espécies, contribuindo para um maior conhecimento da história natural dos anuros neotropicais.
\end{abstract}

Palavras-chave: Ecologia trófica, Mata Atlântica, Amplitude de nicho, Anfíbios.

\section{Introduction}

Information on species trophic ecology is fundamental to describe their ecological niches (Sih 2001), which, in turn, are necessary to understand the functioning of communities and ecosystems (Solé \& Rödder 2010). Several studies have been carried out to investigate the diet of neotropical anurans (López et al. 2009, Sabagh et al. 2012, Barbosa et al. 2014, Kittel \& Solé 2015, Oliveira et al. 2017), however, few evaluate the trophic relationship of resource-sharing species (Sabagh et al. 2010, Oliveira et al. 2015, Moser et al. 2017). Studies on the trophic ecology of coexisting species can provide important information about the use of food resources, thus helping to understand ecological interactions (Begon et al. 2007).

The Hylidae family has 714 known species (Frost 2018) and, in the extreme south of Brazil, they feed mainly on arthropods of the orders Coleoptera, Araneae and Hemiptera (Kwet 2001). The tree frogs Boana bischoffi (Boulenger, 1887) and Boana marginata (Boulenger, 1887) are endemic to the Atlantic Forest biome (Marcelino et al. 2009) and occur in sympatry in the southern Brazilian plateau. Both species have a similar biology but $B$. bischoffi occurs both in forest and open areas, while $B$. marginata occurs exclusively in closed forest areas (Kwet et al. 2010). 
Morphologically and phylogenetically close species tend to use resources in a similar way (Ricklefs \& Trevis 1980) and understanding how this occurs is essential to answer questions about community structure (Lawor 1980). Effective and widely used parameters to understand the species trophic relation are the trophic niche breadth and niche overlap (Pianka 1974, Sabagh \& Carvalho-E-Silva. 2008, Sabagh et al. 2010). In this study, we describe and compare the food composition of $B$. bischoffi and B. marginata, as well as their trophic niches, to provide information about the natural history of these hylids.

\section{Material and Methods}

\section{Study site}

The study was carried out at the southern boundary of the Atlantic Forest, in a region of Mixed Ombrophilous Forest (or Araucaria Forest). Samplings were carried out in a well-preserved portion of Araucaria Forest, inside a Federal Conservation Unit, the National Forest of São Francisco de Paula (29²5'22.4”S; 50²3'11.2”W, 907 a.n.m.), municipality of São Francisco de Paula, state of Rio Grande do Sul, Brazil. The reproductive site sampled was formed by a lake connected to a small stream, where both B. bischoffi and B. marginata were found (Figure 1). The area has an annual precipitation of $2162 \mathrm{~mm}$ distributed evenly throughout the year, subtemperate climate and with an annual average temperature of $14.5^{\circ} \mathrm{C}$ (Backes 1999, Maluf 2000).

\section{Data Collection}

Captures were made through active search (Crump \& Scott Jr 1994) at night from October to November 2015. The individuals found were manually captured and immediately packed in a refrigerated styrofoam box to reduce their digestion's physiological activities (Oliveira et al. 2015). The collections were carried out with the competent Federal Organ authorization, SISBIO (authorization \# - 45861-1). At the laboratory, the animals were euthanized with topical anesthetic (xylocaine), fixed in 10\% formaldehyde and preserved in $70 \%$ alcohol. This procedure was in accordance with the institutional license obtained for experimentation with animals (\# PPCEUA07.2016). Subsequently, each individual was dissected for the removal of gastrointestinal contents (stomach and intestine considered as a single sample). This material was kept in $70 \%$ alcohol until the screening process with a stereomicroscope. In addition to food content, we also collect muscle tissue from individuals for stable isotope analysis, which was part of a complementary study developed by our staff. All collected individuals are housed in the scientific collection of the Laboratory of Ecology of Terrestrial Vertebrates (Boana bischoffi: CHLEVT 1248-1275, 1324, 1325, 1327, 1328, 1342-1352; Boana marginata: CHLEVT 1364-1382, 1384-1392, 1703). Extracted contents were identified until the lowest possible taxonomic level, which was limited by prey digestion level. In general, prey presented a high fragmentation degree and, for this reason, the maximum taxonomic resolution reached mostly the level of order. For each prey category, the number, volume (detailed below) and frequency of occurrence were calculated. Some fragments whose identification was not possible were grouped in the category "others" and only their volume was quantified. Volume was calculated by using the area $\left(\mathrm{mm}^{2}\right)$ occupied by each item with a graph paper support attached to the bottom of the Petri dish, where we evenly spread each item, maintaining a regular height of $1 \mathrm{~mm}$ (Hellawell \& Abel 1971). In order to calculate each item volume $(\mathrm{V})$, the area value $\left(\mathrm{mm}^{2}\right)$ was multiplied by its height ( $1 \mathrm{~mm}$ ) (Oliveira et al., 2015).

\section{Data Analysis}

To measure the importance of each prey category, we used the Index of Relative Importance (IRI): IRI $=(\% \mathrm{~N}+\% \mathrm{P}) \% \mathrm{FO}$, where $\% \mathrm{~N}$ is the relative abundance of each prey in the diet; $\% \mathrm{P}$ is the mass percentage of each prey in the diet; and \%FO is the relative frequency of occurrence of prey (Pinkas et al. 1971, Krebs 1999). The higher the value of IRI, the greater is the importance of each prey in the diet. To analyze the dimension of the trophic niches breadth, we calculated the Levin's Niche Breadth Index (B) (Krebs 1999). This index is defined by: $\mathrm{B}=1 / \Sigma \mathrm{pi}$, where $\mathrm{p}$ is the individual proportion of a given resource $\mathrm{i}$ (taxon) found in the diet. To facilitate comparisons between species, the Standardized Index of Levins (Bsta) was calculated using the following equation: $B s t a=(B-1) /(n-1)$, where $n$ represents the number of resources recorded. Values close to zero are attributed to a specialist diet, while values close to one are attributed to a generalist diet.

To analyze if the trophic niche overlaps between the species, with regards to the degree of similarity between their diets, we used the Trophic Niche Overlap Index of Pianka (Ojk) (Pianka, 1974), defined by the following equation: $\mathrm{O}_{\mathrm{jk}}=\sum_{\mathrm{n}=1}^{0} \mathrm{p}_{\mathrm{ij}} \times \mathrm{p}_{\mathrm{ik}} / \sqrt{\sum_{\mathrm{n}=1}^{0} \mathrm{p}_{\mathrm{ij}}^{2} \times \sum_{\mathrm{n}=1}^{0} \mathrm{p}_{\mathrm{ik}}^{2}}$, where Ojk is the niche overlap index between the species $\mathrm{j}$ and $\mathrm{k}$; pij is equivalent to the proportion of the resource type i relative to the total of resources used by the species j; pik is the proportion of resource i relative to the total of resources used by the species $\mathrm{k}$; and $\mathrm{n}$ is the total number of resource categories used by the species $\mathrm{j}$ and $\mathrm{k}$. The index ranges from 0 to 1 , when there is no overlap or a complete overlap between the species diets, respectively (Krebs, 1999).

\section{Results}

We analyzed the gastrointestinal contents from 43 individuals of $B$. bischoffi and 30 individuals of $B$. marginata. Of these, only two individuals (both $B$. marginata) had their digestive tracts empty. We identified a total of 149 food items, distributed in 18 prey categories. We identified 15 prey categories for B. bischoffi and 12 for B. marginata. According to the Index of Relative Importance (IRI), the two most important prey for both $B$. bischoffi and B. marginata were Araneae $(\operatorname{IRI} \%=45.2$ and 29.1, respectively) and Coleoptera (IRI\% $=25,7$ and 58.6, respectively) (Table 1). The "others" group represented $15.9 \%$ of the total volume in B. bischoffi and 38.9\% in B. marginata. In both species, we found plant material, representing $2.30 \%$ of the total volume of B. bischoffi and $5.10 \%$ of B. marginata (Table 1). Only three prey categories were consumed exclusively by $B$. marginata: Odonata, Isopoda and Formicidae. The number of exclusive prey was higher for B. bischoffi: Lepidoptera, Lepidoptera (larva), Dermaptera, Diptera (larva), Pseudoescorpionida and Diplopoda. However, the two species had a high overlap in their diet, according to the Pianka Niche Overlap Index $(0.90 \mathrm{Ojk})$. In relation to niche breadth, the Levins' Standardized Trophic Niche Index (Bsta) was higher for B. bischoffi (0.42) than for B. marginata (0.35) (Table 1). 


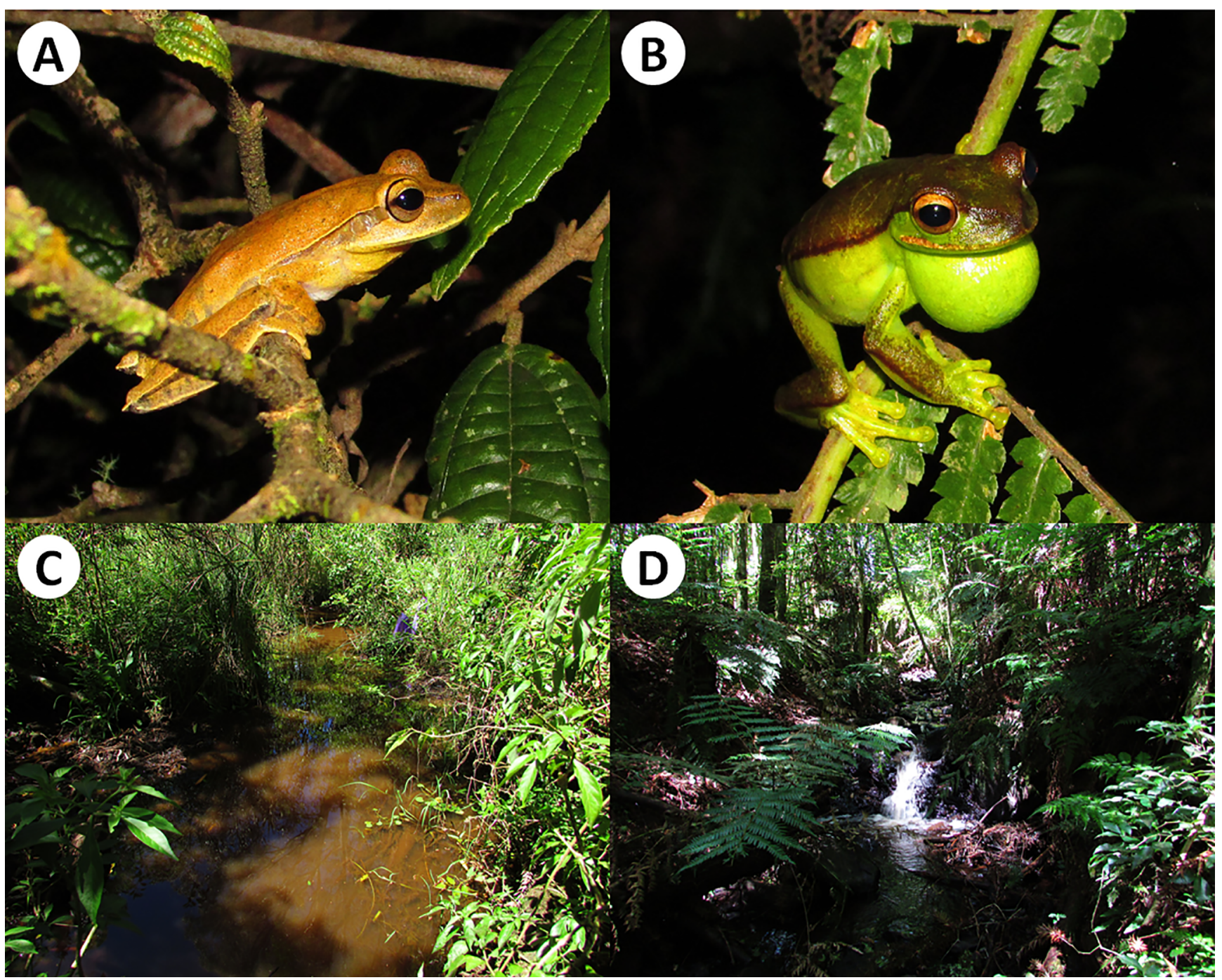

Figure 1. Anurans and sampled environments in the Araucaria Forest at the National Forest of São Francisco de Paula, municipality of São Francisco de Paula, state of Rio Grande do Sul, Brazil. A, Boana bischoff, CHLEVT 1250, adult male, SVL 40.0 mm; B, Boana marginata, CHLEVT 1379, adult male, SVL $50.0 \mathrm{~mm}$; C and D lentic and lotic environments, respectively.

\section{Discussion}

Boana bischoffi and B. marginata exhibited similar composition in their diets. In addition, the most important prey were the same for both species. This similarity in their diets was expected due to phylogenetic proximity between them (Faivovich et al., 2004). Furthermore, it is likely that both species were exposed to the same prey supply since they were collected in the same study site, although in possible different microhabitats. Unfortunately, we do not have data on the prey availability in the habitat, and therefore our results should be interpreted with caution. The taxonomic level of Order could be a limitation for our explanations (Tavares-Cromar \& Williams 1996, Bundy et al. 2011, Pombo et al. 2013). Nevertheless, some basic aspects of food-web, as the mean chain length and linkage complexity vary little within the degree of taxonomic resolution (Thompson \& Townsend 2000), and food webs are best explained by coarser taxonomic ranks, from kingdom to class (Eklöf et al. 2012).
The orders Araneae and Coleoptera are considered very abundant arthropods in the environment (Baretta 2007) and were also recorded in abundance in the study area (Oliveira M. pers. comm.). The importance of Araneae and Coleoptera has also been recorded for several other neotropical anurans (e.g., Maneyro et al. 2004, Miranda et al. 2006, Duré et al. 2009, Rosa et al. 2011, Oliveira et al. 2015, Moser et al. 2017). In addition, spiders and beetles were also the most important prey for other species of the same genus, such as Boana leptolineata, in a region that is similar and close to the studied environment (Barbosa et al. 2014). Coleopterans are a group of highly diverse organisms and very abundant in the environment, especially during the warmer months (Teixeira et al. 2009), making them prey of easy consumption.

Spiders are also a very important prey category for the whole Hylidae family. For species of the genus Scinax, for example, the order Araneae represented the most important prey category in their diets (Sabagh et al. 2010, Kittel \& Solé 2015). In addition, for other 
Moser, C.F. et al.

Table 1. Prey categories found in the gastrointestinal contents of $B$. bischoffi and B. marginata. $\mathrm{N}=$ number of individuals, $\mathrm{V}=$ total volume (in mm ${ }^{3}$ ) occupied by prey category, $\mathrm{FO}=$ prey category's frequency of occurrence, IRI = Index of Relative Importance, $(\%)=$ percentage values over total.

\begin{tabular}{|c|c|c|c|c|c|c|c|c|}
\hline \multirow{2}{*}{ Prey categories } & \multicolumn{4}{|c|}{ Boana bischoffi } & \multicolumn{4}{|c|}{ Boana marginata } \\
\hline & $\% \mathbf{N}$ & $\% \mathrm{~V}$ & $\%$ FO & IRI\% & $\% \mathbf{N}$ & $\% \mathrm{~V}$ & $\%$ FO & IRI\% \\
\hline Araneae & 26.50 & 13.40 & 54.80 & 45.20 & 21.60 & 13.30 & 35.70 & 29.08 \\
\hline Diptera & 10.20 & 12.30 & 19.00 & 8.87 & 7.80 & 1.70 & 14.30 & 3.18 \\
\hline Acarina & 5.10 & 0.10 & 11.90 & 1.28 & 7.80 & 0.02 & 14.30 & 2.62 \\
\hline Coleoptera (larva) & 9.20 & 7.20 & 23.80 & 8.09 & 5.90 & 3.40 & 10.70 & 2.34 \\
\hline Orthoptera & 5.10 & 6.20 & 11.90 & 2.79 & 3.90 & 0.40 & 7.10 & 0.73 \\
\hline Hymenoptera & 5.10 & 4.80 & 11.90 & 2.44 & 2.00 & 0.60 & 3.60 & 0.21 \\
\hline Lepidoptera & 2.00 & 2.00 & 4.80 & 0.40 & 0.00 & 0.00 & 0.00 & 0.00 \\
\hline Lepidoptera (larva) & 3.00 & 3.80 & 7.10 & 1.01 & 0.00 & 0.00 & 0.00 & 0.00 \\
\hline Odonata & 0.00 & 0.00 & 0.00 & 0.00 & 3.90 & 7.00 & 3.60 & 0.91 \\
\hline Isopoda & 0.00 & 0.00 & 0.00 & 0.00 & 2.00 & 1.30 & 3.60 & 0.27 \\
\hline Hymenoptera Formicidae & 0.00 & 0.00 & 0.00 & 0.00 & 2.00 & 0.04 & 3.60 & 0.17 \\
\hline Pseudoscorpionida & 1.00 & 0.10 & 2.40 & 0.05 & 0.00 & 0.00 & 0.00 & 0.00 \\
\hline Diplopoda & 1.00 & 0.10 & 2.40 & 0.06 & 0.00 & 0.00 & 0.00 & 0.00 \\
\hline Plant material & 0.00 & 2.30 & 0.00 & - & 0.00 & 5.10 & 0.00 & - \\
\hline Other & 0.00 & 15.90 & 0.00 & - & 0.00 & 38.90 & 0.00 & - \\
\hline Niche breadth & \multicolumn{4}{|c|}{0.42} & \multicolumn{4}{|c|}{0.35} \\
\hline
\end{tabular}

species of Boana, such as B. albopunctata (De Araújo et al., 2007), Boana raniceps (Sabagh et al. 2010), B. leptolineata (Barbosa et al. 2014) and B. pulchella (Da Rosa et al. 2011), spiders have proved to be an important part of these species' food composition. The presence of spiders in the diet of these hylids is probably related to the fact that predator and prey use the same micro-habitat, suspended in shrubs, facilitating the encounter of prey (De Araújo et al. 2007, Barbosa et al. 2014).

Boana bischoffi and B. marginata demonstrated a similar trophic niche breadth, with generalist characteristics. The niche breadths recorded in this study were similar to those recorded for Aplastodiscus perviridis $(\mathrm{Bsta}=0.27$, Oliveira et al. 2017) and B. pulchella $(\mathrm{Bsta}=$ 0.31 , Oliveira 2014), but smaller than those recorded for $B$. leptolineata $($ Bsta $=0.51$, Barbosa et al. 2014), B. raniceps $($ Bsta $=0.64$, Sabagh et al. 2010) and Scinax acuminatus (Bsta $=0.48$, Sabagh et al. 2010). In general, B. bischoffi and B. marginata have large niches in comparison to other species [e.g., Rhinella arenarum and R. dorbignyi (Isacch \& Barg 2002), R. icterica (Sabagh \& Carvalho-e-Silva 2008), Physalaemus biligonigerus (Oliveira et al. 2015), P. gracilis and P. lisei (Moser et al. 2017) and Aplastodiscus perviridis (Oliveira et al. 2017)]. Our results suggest a more generalist behavior of the studied hylids species, feeding on similar quantities from a greater prey variety (Sabagh et al. 2010, Barbosa et al. 2014).
The high niche overlap recorded for B. marginata and B. bischoffi was expected since congeneric species that share the same habitat tend to have similar diets (Duellman \& Trueb 1986, Guidali et al. 2000, Sabagh et al. 2010). The high niche overlap was also recorded for Dendropsophus nanus and D. sanborni $(87.2 \%$, Menin et al. 2005), Physalaemus lisei and P. gracilis (98\%, Moser et al. 2017), and Phyllomedusa burmeisteri and Pithecopus rohdei (82\%, Lima et al. 2010). The trophic overlap of hylids from different genera, such as Boana raniceps and Scinax acuminatus (60\%, Sabagh et al. 2010), was considerably lower compared to hylids from the same genus.

\section{Acknowledgments}

We would like to thank our friends at the Laboratório de Ecologia de Vertebrados Terrestres - UNISINOS for their contribution. We would also like to thank FAPERGS, CAPES and CNPq for their financial support.

\section{Author contributions}

Camila Moser: Collected the data, participated in the screening, analyses and article elaboration

Mateus de Oliveira: Collected the data, participated in the screening, analyses and article elaboration 
Fernanda Avila: Collected the data, participated in the screening, analyses and article elaboration

Diogo Dutra-Araújo: Collected the data and participated in the article elaboration

Renata K. Farina: Collected the data and participated in the screening.

Alexandro Marques Tozetti: Participated in the analyses and article elaboration

\section{Conflicts of interest}

The authors declare that they have no conflict of interest related to the publication of this manuscript.

\section{References}

ANDERSON, A.M., HAUKOS, D.A. \& ANDERSON, J.T. 1999. Diet composition of three anurans from the Playa Wetlands of Northwest Texas. Copeia 1999(2):515-520.

BACKES, A. 1999. Condicionamento climático e distribuicão geográfica de Araucaria angustifolia (Bertol.) Kuntze no Brasil: 2. Pesquisas, Bot, 49: 31-51.

BARBOSA, A.S., DE OLIVEIRA, M., LEAL, A.L., VON MÜHLEN, C., SPINDLER, C.S. \& SOLÉ, M. 2014. Diet of Hypsiboas leptolineatus (Braun and Braun, 1977) (Amphibia: Anura: Hylidae) during the breeding season. Herpetol. (7):505-508.

BARETTA, D. 2007. Fauna do solo e outros atributos edáficos como indicadores da qualidade ambiental em áreas com Araucaria angustifolia no Estado de São Paulo. Doctoral Thesis, Escola Superior de Agricultura Luiz de Queiroz, São Paulo, Brasil.

BEGON, M., TOWNSEND, C.R. \& HARPER, J.L. 2007. Ecologia: de indivíduos a ecossistemas. 4 ed. Artmed, Porto Alegre, Rio Grade do Sul, Brazil.

BUNDY, A., LINK, J.S., SMITH, B.E. \& COOK, A.M. 2011. You are what you eat, whenever or wherever you eat it: an integrative analysis of fish food habits in Canadian and U.S.A. waters. J. Fish Biol. 78: 514-539.

CRUMP, M.L., SCOTT JR., N.J. 1994. Visual encounter surveys. In: Measuring and Monitoring Biological Diversity-Standard Methods for Amphibians, p. 84-92. Heyer, W.R., Donnelly, M.A., McDiarmid, R.W., Hayek, L.A.C., Foster, M.S, Eds., Washington, Smithsonian Institution Press.

DA ROSA, I.D., CANAVERO, A., MANEYRO, R. \& CAMARGO, A. 2011. Trophic niche variation and individual specialization in Hypsiboas pulchellus (Duméril and Bibron, 1841) (Anura, Hylidae) from Uruguay. South Am J. Herpetol. 6:98-106.

DE ARAÚJO, F.R.R.C., BOCCHIGLIERI, A. \& HOLMES, R.M. 2007. Ecological aspects of the Hypsiboas albopunctatus (Anura, Hylidae) in central Brazil. Neotrop. Biol. Conserv. 2(3):165-168.

DUELLMAN, W.E., \& TRUEB, L. 1994. Biology of amphibians. JHU press, London.

DURÉ, M.I., KEHR, A.I. \& SCHAEFER, E.F. 2009. Niche overlap and resource partitioning among five sympatric bufonids (Anura, Bufonidae) from northeastern Argentina. Phyllomedusa 8:27-39.

EKLÖF, A., HELMUS, M.R., MOORE, M. \& ALLESINA, S. 2012. Relevance of evolutionary history for food web structure. Proceeding of the Royal Society B 279:1588-1596.

FAIVOVICH, J., GARCIA, P.C., ANANIAS, F., LANARI, L., BASSO, N.G. \& WHEELER, W. C. (2004). A molecular perspective on the phylogeny of the Hyla pulchella species group (Anura, Hylidae). Mol. Phylogenet. Evol. 32(3):938-950.

FROST, D.R. 2018. Amphibians Species of the World: an Online Reference. Version 6.0. (07 September 2018). Electronic Database accessible at http:// research.amnh.org/herpetology/amphibia/index.html. American Museum of Natural History, New York, USA.
GUIDALI, F., SCALI, S. \& CARETTONI, A. 2000. Diet and trophic niche overlap of two ranid species in northern Italy. Ital. J. Zool. 67(1):67-72.

ISACCH, J.P. \& BARG, M. 2002. Are bufonid toads specialized ant-feeders? A case test from the Argentinian flooding pampa. J. Nat. Hist. 36(16):20052012.

HELLAWELL, J.M. \& ABEL, R. 1971. A rapid volumetric method for the analysis of the food of fishes. J. Fish Biol. 3(1):29-37.

KITTEL, R.N. \& SOLÉ, M. 2015. Diet of the striped snouted treefrog Scinax squalirostris (Anura: Hylidae) in southern Brazil. Herpetol. N. 8:157-160.

KREBS, C.J. 1999. Ecological Methodology. 2 ed. Benjamin Cummings, California, USA.

KWET, A. 2001. Frösche im brasilianischen Araukarienwald: Diversität, Reproduktion und Ressourcenaufteilung. Naturund-Tier-Verlag, Münster, $192 \mathrm{pp}$.

KWET, A., LINGNAU, R. \& DI-BERNARDO, M. 2010. Pró-Mata: Anfíbios da Serra Gaúcha Sul do Brasil. Brasilien-Zentrum, University of Tübingen, Germany.

LAWLOR, LR. 1980. Overlap, similarity and competition coefficients. Ecol. 61:245-251.

LIMA, P.J.E., ROEDDER, D. \& SOLE, M. 2010. Diet of two sympatric Phyllomedusa (Anura: Hylidae) species from a cacao plantation in southern Bahia, Brazil. North West. J. Zool. 6:13-24.

LÓPEZ, J.A., SCARABOTTI, P.A., MEDRANO, M.C. \& GHIRARDI, R. 2009. Is the red spotted green frog Hypsiboas punctatus (Anura: Hylidae) selecting its preys?: The importance of prey availability. Revista de biologia tropical 57:847-857.

MALUF, J. R. 2000. Nova classificação climática do Estado do Rio Grande do Sul. Rev. Bras. Agrometeorol. 8:141-150.

MANEYRO, R., NAYA, D.E., ROSA, I., CANAVERO, A. \& CAMARGO, A. 2004. Diet of the South American frog Leptodactylus ocellatus (Anura, Leptodactylidae) in Uruguay. Iheringia Ser. Zool. 94:57-61.

MARCELINO, V.R., HADDAD, C.F. \& ALEXANDRINO, J. 2009. Geographic distribution and morphological variation of striped and nonstriped populations of the Brazilian Atlantic Forest treefrog Hypsiboas bischoffi (Anura: Hylidae). J. Herpetol. 43:351-361.

MENIN, M., ROSSA-FERES, D.D.C. \& GIARETTA, A.A. 2005. Resource use and coexistence of two syntopic hylid frogs (Anura, Hylidae). Revista Brasileira de Zoologia 22(1):61-72.

MIRANDA, T., EBNER M., SOLÉ, M. \& KWET, A. 2006. Spatial, seasonal and intrapopulational variation in the diet of Pseudis cardosoi (Anura: Hylidae) from the Araucaria Plateau of Rio Grande do Sul, Brazil. South Am. J. Herpetol. 1:121-130

MOSER, C.F., AVILA, F.R., OLIVEIRA, M. \& TOZETTI, A.M. 2017. Diet composition and trophic niche overlap between two sympatric species of Physalaemus (Anura, Leptodactylidae, Leiuperinae) in a subtemperate forest of southern Brazil. Herpetol. N. 10:9-15.

OLIVEIRA, M. 2014. Efeito dos fatores ambientais sobre a dieta de anuros em banhados subtemperados do extremo sul neotropical. Dissertação de mestrado. Universidade do Vale do Rio dos Sinos, São Leopoldo.

OLIVEIRA, M., GOTTSCHALK, M.S., LOEBMANN, D., DOS SANTOS, M.B., MIRANDA, S., ROSA, C. \& TOZETTI, A.M. 2015. Diet composition and niche overlap in two sympatric species of Physalaemus (Anura, Leptodactylidae, Leiuperinae) in coastal subtemperate wetlands. Herpetol. N. 8: 173-177.

OLIVEIRA, M., MOSER, C.F., AVILA, F.R., BUENO, J.A. \& TOZETTI, A.M. (2017). Diet of Aplastodiscus perviridis Lutz 1950 (Anura, Hylidae) in subtemperate forests of southern Brazil. Neotrop. Biol. Conserv. 12(3):181-184.

PIANKA, E.R. 1974. Niche overlap and diffuse competition. Proc. Natl. Acad. Sci. 71(5):2141-2145

POMBO, M., DENADAI, M.R., TURRA, A. 2013. Seasonality, Dietary Overlap and the Role of Taxonomic Resolution in the Study of the Diet of Three Congeneric Fishes from a Tropical Bay. PLoS ONE 8(2):1-10. 
RICKLEFS, R.E. \& TREVIS, J. 1980. A morphological approach to the study of avian community organization. Auk 97:321-328.

SABAGH, L.T. \& CARVALHO-E-SILVA, A.M. 2008. Feeding overlap in two sympatric species of Rhinella (Anura: Bufonidae) of the Atlantic Rain Forest. Revista Brasileira de Zoologia 25(2):247-253.

SABAGH, L.T., FERREIRA, V.L. \& ROCHA, C.F.D. 2010. Living together, sometimes feeding in a similar way: the case of the syntopic hylid frogs Hypsiboas raniceps and Scinax acuminatus (Anura: Hylidae) in the Pantanal of Miranda, Mato Grosso do Sul State, Brazil. Brazil. Braz. J. Biol. 70(4):955-959.

SABAGH, L.T. \& ROCHA, C.F.D. 2012. Diet of the toad Rhinella icterica (Anura: Bufonidae) from Atlantic Forest Highlands of southeastern Brazil. Biota Neotrop. 12(4):258-262.
SIH, A. \& CHRISTENSEN, B. 2001. Optimal diet theory: when does it work, and when and why does it fail? Anim. Behav. 61(2):379-390.

TAVARES-CROMAR A.F \& WILLIAMS D.D. 1996. The Importance of Temporal Resolution in Food Web Analysis: Evidence from a DetritusBased Stream. Ecol. Monogr. 66:91-113.

TEIXEIRA, C.C.L., HOFFMANN, M. \& SILVA-FILHO, G. 2009. Comunidade de Coleoptera de solo em remanescente de Mata Atlântica no estado do Rio de Janeiro, Brasil. Biota Neotropica 9 (4):091-095

THOMPSON R.M. \& TOWNSEND C.R. 2000. Is resolution the solution?: the effect of taxonomic resolution on the calculated properties of three stream food webs. Freshw. Biol. 44:413-422.

Received: 09/03/2018

Revised: 08/09/2018

Accepted: $31 / 10 / 2018$

Published online: 29/11/2018 